北海道南部の砂質海岸に生息するナミノリソコェビ科端脚類の発生と生長

$$
\text { 上平幸好 }
$$

函館大学生物学研究室

\title{
DEVELOPMENT AND GROWTH IN DOGIELINOTID AMPHIPODS ON SANDY BEACHES IN SOUTHERN HOKKAIDO, JAPAN
}

\author{
Yukiyoshi KaMIHIRA \\ Biological Laboratory, Hakodate College, Hakodate 042, Japan
}

\begin{abstract}
This paper deals with the development and growth of two dogielinotid amphipods in southern Hokkaido, Japan. The early developmental stages of Haustorioides japonicus and $H$. munsterhjelmi were observed, and five clearly defined stages were regognized within the brood pouch of female by morphological characteristics. The characteristics of juveniles just after hatching were observed in detail, and compared with those of adult specimens. From these observation, it was clear that these juveniles could be identified immediatory to the species level. Loss of embryos in brood pouch was about $18-41 \%$ just before hatching, and $37-56 \%$ just before releace from the brood pouch of $H$. japonicus. High mortality during early development were observed between stage III and stage IV, and between stage V and stage VI.
\end{abstract}

ナミノリソコエビ科端脚類 (Dogielinotidae) の詳細な生活史を知る一環として, 北海道沿岸 に生息する Haustorioides 属の二種, H. japonicus と H. munsterhjelmi の発生と生長の観察 を行った，すなわち卵発生による形態変化の記録とステージ区分，育児囊内の卵のステージ別 減耗率と各調查地での相違, 孵化率の観察, 餒化直後の幼体の形態記載, 生息地個体群を母集 団とする定期採集標本にもとづいた生長観察, 脱皮回数の調査がそれである。これよりフクロ エビ上目に包括されるナミノリソコエビ科端脚類の育児囊の保護機能について考察した。

\section{材料と方法}

北海道渡島半島の 砂質海岸, 岩内町大浜・瀬棚町三本杉海岸・函館大森浜・伊達有珠海岸と, 同半島部と胴体部の接点にある武川町汐見浜の計 5 か所で, 原則として月に一度採集した標本 を観察に供した（詳細は上平1990を参照)。育児蘘内の卵減耗率は産卵直後の未分割卵を抱く雌 の平均体長の平均抱卵数を基準として, 各発生段階にある平均抱卵数を比較することより推定 した。脱皮回数の推定は室内飼育による脱皮観察と, 野外で採集した標本より触角節数と胸肢 末端節剛毛数のそれぞれの变化を锶察することにより行った。 
発生：成体雌の脱皮後に産出された Haustorioides japonicus の卵は, ゼラチン状物質に包 まれ卵塊をなしていた。産卵直後の卵は互いに接触面で凹み多面体をなしていたが時間の経過 にともない棈円形を呈した。覆卵葉が充分に伸長して育児囊が形成されるとゼラチン状の物質 は消失し，こののち卵はばらばらになって育児囊に保持された。野外で採集しホルマリン固定 された雌850例の顕微鏡観察中，ゼラチン状物質に包まれた状態での卵が観察されたのは 1 例の みで, この物質はごく短時間だけ存在するようである。

卵は灰青色を呈し未受精卵の大きさは $300 \times 250 \mu \mathrm{m}$ であった（PI. I-1）。受精卵は受精膜の 形成により区別できて,その大きさは $350 \times 250 \mu \mathrm{m}$ である (P1. I-2)。等黄卵で卵割は16細胞期 まで等割であった (Pl. I-3/8)。水温 $23 \pm 1^{\circ} \mathrm{C}$ で受精後約 24 時間に胚盤形成期に達し(P1. I-9), 40時間後に尾部溝が形成された（P1．I-10)。50時間後に背器ができて (Pl. I-12), 付属肢原基も 観察された（P1. I-10/11）。95時間後に赤色の眼色素が現れ（P1. II-17)，付属肢の分化が顕著と なって触角も形成された。120時間後に背器は退化し心蔵の拍動は規則的となって, 腸における 筋肉運動が観察された。150時間前後で特に活発な体全体の運動をするようになり受精後約155 時間で餒化した。なお卿膜の破瓜は第 3 尾肢と尾節板付近よりおきた。

H. munsterhjelmi の発生も, 卵の大きさ $(450 \times 350 \mu \mathrm{m})$ と各ステージ間の所要時間の違い のあった他は H. japonicus と基本的に同じであった。

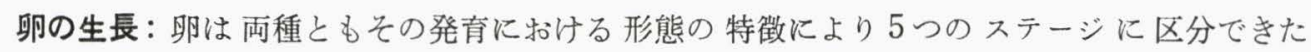
(Fig. 1)。その各ステージの主な特徴は次のと拈りである。

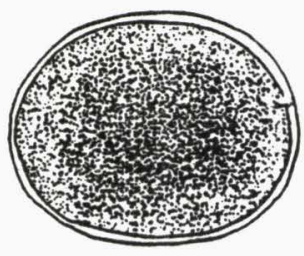

Stage I.

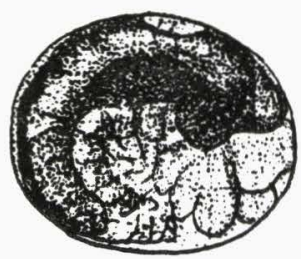

Stage IV.

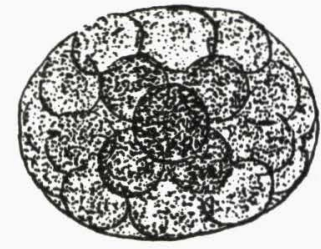

Stage II.

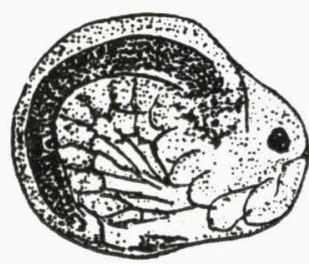

Stage $\mathrm{V}$.

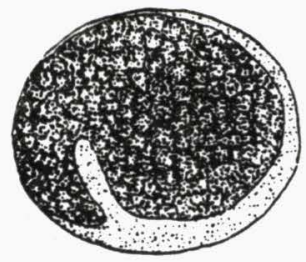

Stage III.

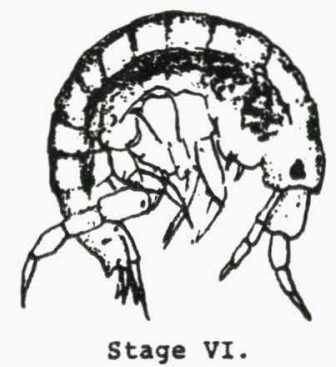

Fig. 1. Embryonic development of Haustorioides japonicus. H. japonicus の発生段階. 


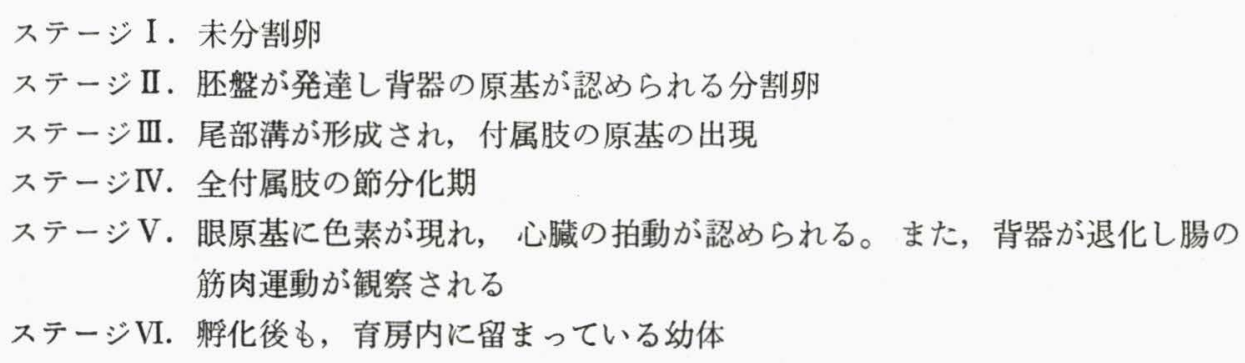

各発育段階にある卵の長軸と短軸の平均長を計測し Fig. 2 に示した。時間の経過にともな い卵径は増大し, 長軸に対する短軸の比率は H. japonicus のばあい, ステージIから順に 1: $0.71,1: 0.87,1: 0.89,1: 0.85,1: 0.85$ と変化した。 H. munsterhjelmi では $1: 0.78$, $1: 0.82,1: 0.84,1: 88,1: 0.88$ と変化して棈円形から僅かながら丸みを帯びた。孵化直前 に卵径は最大になり，この時のサイズは H. japonicus で $750 \times 600 \mu \mathrm{m}, H$. munsterjhelmi で $900 \times 750 \mu \mathrm{m}$ であった。ステージIVで少し大きな増加が観察されたが，この時期は付属肢 の分化がなされるときであった。

卵の減耗：育児囊に産出された卵の中には全く発生しないまま崩壊したり, 途中で発生が停 止するもののあることを顕微鏡観察で知った。また発生が進むにつれて卵径が大きくなり， 多数抱卵されていると育児囊を 形成している 覆卵葉が, 卵の生長のため内部より拡張され, 孵化直前の卵が 育児褧より脱落することがあった。以上のような理由で, 卵が育児囊に産出さ

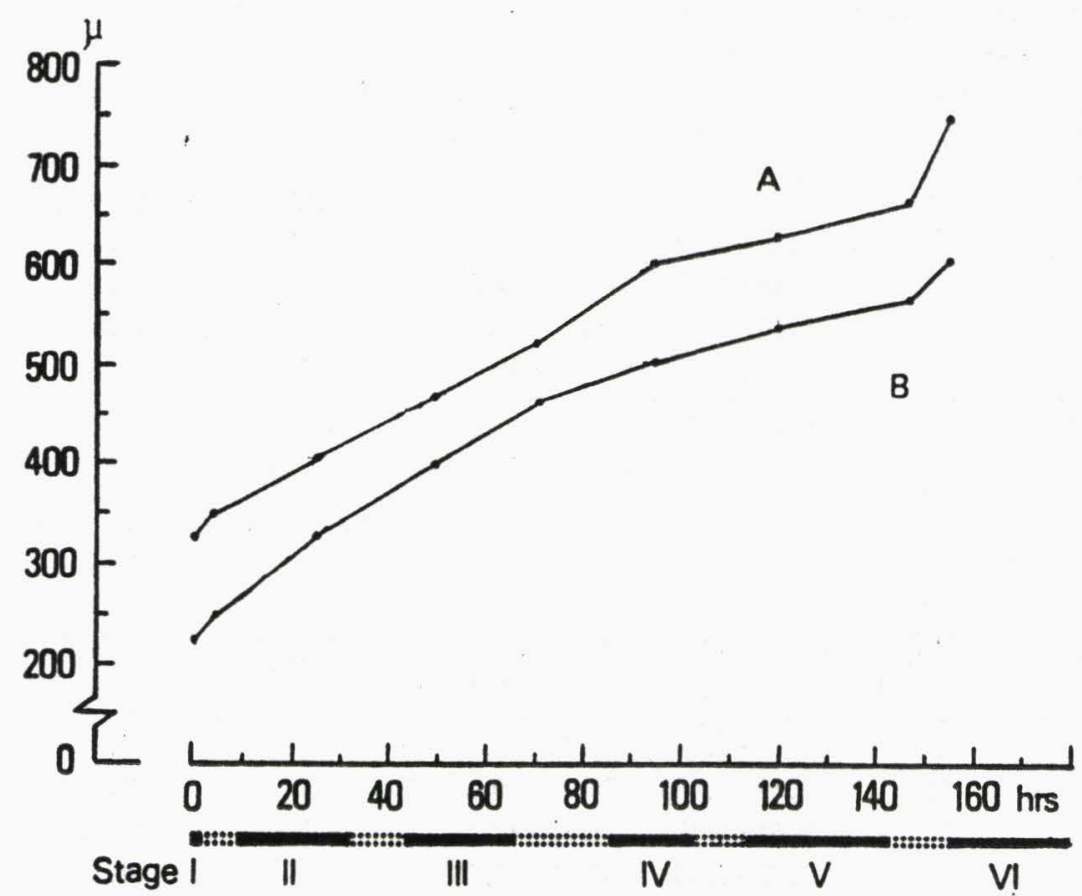

Fig. 2. Mean length (A) and width (B) of embrosy of Haustorioides japonicus at each stage of development. H. japonicus の卵発生, 各ステージに拈ける平均長と平均幅. 
れてから捊化するまでの 減耗率を調べた。抱卵数は調查時によって違いのあることが知られて いるので (上平 印刷中), この観察には各調査地に拈ける産卵最盛期時の標本を用いた。

まず各ステージの卵を抱くH. japonicus の雌の平均体長間に, 統計的に有意な差があるか不 かを検定した。その結果，1\%の危険率で差異は認められなかった。したがって各ステージの卵 を抱いている雌は，その産卵時に同数の卵を産出したものと仮定することができた。そして， もしステージIに拁ける平均抱卵数と他のステージの間に, 統計的有意差が認められたならそ れは前述の理由による減耗であるとみなした。

岩内の H. japonicus の第 1 世代の減耗率は, 眼色素の発現によって特徽づけられるステー ジVまでに約36\%に達した (Table 1)。・ステージ I とII との間で約 $12 \%$ の大きな減耗があり, ステーシ IVとVとの間で約 $9 \%$ の減耗が観察された。第 2 世代の減耗率は十分な資料を集めれな かったので不明である。

瀬棚の第 1 世代の減耗率は, ステージVまでに約34\%に達していた (Table 2)。ステージ I とII との間で約 $8 \%$ の減耗があり，ステージIII IV との間で約 $17 \%$ の大さな減耗が観察された。 第 2 世代の減耗率を知るだけの資料は集めることができなかった。

函館での H. japonicus の減耗率を Table 3 に示した。ステージが進むにつれて抱卵数は減 少しており，眼色素の発現によって特徵づけられるステージVまでの減耗は約 $18 \%$ を記録して 岩内や瀬棚の減耗率よりも低かった。またステージII とIVとの間に10\%の減耗があった。ステ

Table 1. Loss rate of embryos during development in Haustorioides japonicus of Iwanai in late-June, 1988. 岩内大浜に㧍ける H. japonicus の卵発生での減耗率.

\begin{tabular}{ccccccc}
\hline $\begin{array}{c}\text { Stage of } \\
\text { development }\end{array}$ & $\begin{array}{c}\text { No. of } \\
\text { females } \\
\text { examined }\end{array}$ & $\begin{array}{c}\text { Mean body } \\
\text { length (mm) } \\
\pm \text { s. v. }\end{array}$ & $\begin{array}{c}\text { Mean brood } \\
\text { size } \pm \text { s. v. }\end{array}$ & $\begin{array}{c}\text { Brood size/ } \\
\text { body length } \\
\text { ratio }\end{array}$ & $\begin{array}{c}\text { Survival } \\
\text { rate }(\%)\end{array}$ & $\begin{array}{c}\text { Loss } \\
\text { rate } \\
(\%)\end{array}$ \\
\hline I & 11 & $9.40 \pm 0.30$ & $89.72 \pm 8.10$ & 9.54 & 100.00 & 0 \\
II & 10 & $9.45 \pm 0.39$ & $79.50 \pm 10.35$ & 8.41 & 88.16 & 11.84 \\
III & 10 & $9.40 \pm 0.47$ & $71.70 \pm 10.87$ & 7.63 & 79.98 & 20.02 \\
IV & 12 & $9.48 \pm 0.26$ & $65.67 \pm 12.64$ & 6.93 & 72.64 & 27.36 \\
V & 10 & $9.54 \pm 0.41$ & $58.22 \pm 15.22$ & 6.10 & 63.94 & 36.06 \\
\hline VI & 6 & $9.74 \pm 0.28$ & $42.17 \pm 12.25$ & 4.33 & 46.11 & 53.89 \\
\hline
\end{tabular}

Table 2. Loss rate of embryos during development in Haustorioides japonicus of Setana in late-June, 1988. 瀬棚三本杉海岸における H. japonicus の卵発生での減耗率.

\begin{tabular}{ccccccc}
\hline $\begin{array}{c}\text { Stage of } \\
\text { development }\end{array}$ & $\begin{array}{c}\text { No. of } \\
\text { females } \\
\text { examined }\end{array}$ & $\begin{array}{c}\text { Mean body } \\
\text { length }(\mathrm{mm}) \\
\pm \mathrm{s.v.}\end{array}$ & $\begin{array}{c}\text { Mean brood } \\
\text { size } \pm \mathrm{s.v} .\end{array}$ & $\begin{array}{c}\text { Brood size/ } \\
\text { body length } \\
\text { ratio }\end{array}$ & $\begin{array}{c}\text { Survival } \\
\text { rate }(\%)\end{array}$ & $\begin{array}{c}\text { Loss } \\
\text { rate } \\
(\%)\end{array}$ \\
\hline I & 14 & $9.58 \pm 0.43$ & $85.14 \pm 9.81$ & 8.89 & 100.00 & 0 \\
II & 15 & $9.59 \pm 0.26$ & $78.33 \pm 9.30$ & 8.17 & 91.90 & 8.10 \\
III & 15 & $9.54 \pm 0.17$ & $71.73 \pm 12.61$ & 7.52 & 84.59 & 15.41 \\
IV & 16 & $9.55 \pm 0.19$ & $57.00 \pm 11.08$ & 5.97 & 67.15 & 32.85 \\
V & 12 & $9.57 \pm 0.30$ & $56.17 \pm 8.93$ & 6.87 & 66.03 & 33.97 \\
\hline VI & 2 & $9.38 \pm 0.53$ & $36.00 \pm 1.41$ & 3.84 & 43.69 & 56.31 \\
\hline
\end{tabular}


ージVとと Vとの間には減耗は少なく $(3 \%)$ ， ステージにVIに移るとき $25 \%$ の高い減耗が観察さ れた。餒化した幼体が育児翼に留まっていたステージVIでの平均幼体数は, ステージ I の抱卵 数の63\%で，隇耗率は37\%に達した。

伊達の第 1 世代の滅耗率はステージVまでに約 $39 \%$ に達した。ステージ III と IV との間で約 $12 \%$ 減耗があり，ステージ IV とV の間で約 18\%の大きな減耗が観察された (Table 4)。第 2 世代の滅耗率は, ステージVまでに約 $28 \%$ であった (Table 5)。ステージ III と IV との間で約

Table 3. Loss rate of embryos during development in Haustorioides japonicus of Hakodate in late-June, 1980 . 函館大森浜に抢ける $H$. japonicus の卵発生での減耗率.

\begin{tabular}{ccccccc}
\hline $\begin{array}{c}\text { Stage of } \\
\text { development }\end{array}$ & $\begin{array}{c}\text { No. of } \\
\text { females } \\
\text { examined }\end{array}$ & $\begin{array}{c}\text { Mean body } \\
\text { length }(\mathrm{mm}) \\
\pm \text { s. v. }\end{array}$ & $\begin{array}{c}\text { Mean brood } \\
\text { size } \pm \text { s. v. }\end{array}$ & $\begin{array}{c}\text { Brood size/ } \\
\text { body length } \\
\text { ratio }\end{array}$ & $\begin{array}{c}\text { Survival } \\
\text { rate }(\%)\end{array}$ & $\begin{array}{c}\text { Loss } \\
\text { rate } \\
(\%)\end{array}$ \\
\hline I & 43 & $10.34 \pm 0.37$ & $88.93 \pm 12.53$ & 8.60 & 100.00 & 0 \\
II & 44 & $10.35 \pm 0.37$ & $87.11 \pm 11.38$ & 8.42 & 97.88 & 2.12 \\
III & 47 & $10.34 \pm 0.36$ & $85.02 \pm 11.64$ & 8.22 & 95.59 & 4.41 \\
IV & 49 & $10.35 \pm 0.37$ & $76.04 \pm 8.88$ & 7.35 & 85.41 & 14.59 \\
V & 41 & $10.44 \pm 0.41$ & $73.90 \pm 10.28$ & 7.08 & 82.26 & 17.74 \\
\hline VI & 31 & $10.48 \pm 0.54$ & $57.03 \pm 12.99$ & 5.45 & 63.30 & 36.70 \\
\hline
\end{tabular}

Table 4. Loss rate of embryos during development in Haustorioides japonicus of Usu in late-May, 1986. 伊達有珠海岸における H. japonicus 第 1 世代の卵発生での減耗率.

\begin{tabular}{ccccccc}
\hline $\begin{array}{c}\text { Stage of } \\
\text { development }\end{array}$ & $\begin{array}{c}\text { No. of } \\
\text { females } \\
\text { examined }\end{array}$ & $\begin{array}{c}\text { Mean body } \\
\text { length (mm) } \\
\text { 土s. v. }\end{array}$ & $\begin{array}{c}\text { Mean brood } \\
\text { size } \pm \text { s. v. }\end{array}$ & $\begin{array}{c}\text { Brood size/ } \\
\text { body length } \\
\text { ratio }\end{array}$ & $\begin{array}{c}\text { Survival } \\
\text { rate (\%) }\end{array}$ & $\begin{array}{c}\text { Loss } \\
\text { rate } \\
(\%)\end{array}$ \\
\hline I & 28 & $9.07 \pm 0.49$ & $79.45 \pm 12.51$ & 8.76 & 100.00 & 0 \\
II & 29 & $9.06 \pm 0.40$ & $79.31 \pm 15.55$ & 8.75 & 99.89 & 0.11 \\
III & 25 & $9.05 \pm 0.64$ & $71.84 \pm 14.16$ & 7.94 & 90.64 & 9.36 \\
IV & 29 & $9.08 \pm 0.51$ & $62.89 \pm 19.71$ & 6.92 & 79.00 & 21.00 \\
V & 27 & $9.06 \pm 0.65$ & $48.22 \pm 13.97$ & 5.32 & 60.73 & 39.27 \\
\hline VI & 7 & $8.96 \pm 0.73$ & $21.14 \pm 7.36$ & 2.35 & 26.82 & 73.18 \\
\hline
\end{tabular}

Table 5. Loss rate of embryos during development in Haustorioides japonicus of Usu in mid-August, 1986. 伊達有珠海岸に新ける H. japonicus の第 2 世代の卵発生での減耗淬.

\begin{tabular}{ccccccc}
\hline $\begin{array}{c}\text { Stage of } \\
\text { development }\end{array}$ & $\begin{array}{c}\text { No. of } \\
\text { females } \\
\text { exomined }\end{array}$ & $\begin{array}{c}\text { Mean body } \\
\text { length (mm) } \\
\pm \text { s. v. }\end{array}$ & $\begin{array}{c}\text { Mean brood } \\
\text { size } \pm \mathbf{s .} \Lambda .\end{array}$ & $\begin{array}{c}\text { Brood size/ } \\
\text { body length } \\
\text { ratio }\end{array}$ & $\begin{array}{c}\text { Survival } \\
\text { rate }(\%)\end{array}$ & $\begin{array}{c}\text { Loss } \\
\text { rate } \\
(\%)\end{array}$ \\
\hline I & 20 & $6.75 \pm 0.38$ & $36.80 \pm 6.53$ & 5.45 & 100.00 & 0 \\
II & 24 & $6.78 \pm 0.35$ & $35.54 \pm 6.58$ & 5.24 & 96.15 & 3.85 \\
III & 24 & $6.75 \pm 0.31$ & $35.46 \pm 6.27$ & 5.24 & 96.15 & 3.85 \\
IV & 26 & $6.76 \pm 0.33$ & $33.08 \pm 7.28$ & 4.89 & 89.72 & 10.28 \\
V & 25 & $6.75 \pm 0.38$ & $26.32 \pm 7.08$ & 3.90 & 71.56 & 28.44 \\
\hline VI & 10 & $6.96 \pm 0.21$ & $25.56 \pm 7.20$ & 3.67 & 67.34 & 32.66 \\
\hline
\end{tabular}


6\%減耗があり，ステージIVとVの間で約18の大きな減耗が観察された。伊達のステージVま での減耗率は両世代とも函館の観察結果よりも高かったが，岩内や瀬棚の結果とほぼ同じであ った。

H. munsterhjelmi の減耗率は眼色素が現れ 餒化するまでの ステージVで約 $41 \%$ であった (Table 6)。ステージ I とII の間で $9 \%$ ，ステージIIIか スVとなる付属肢形成時に16\%の減耗が 観察された。ステージI Jら V となる眼色素発現期に14\%の減耗があり，幼体のまま育児露に 留まっているステージVIまでの減耗率は約 $49 \%$ \%゙った。

次に H. japonicus の各ステージ間の卵減耗率に, 調查地点間で違いが有るかを調べた(Table 7)。岩内でステージ I とII との間に約 $12 \%$ の大きな減耗が記録された。しかし 全調查地点のス テージII までの平均減耗率は低く $5 \%$ であった。ステージ II とIIIの間に $5.5 \%$ の減耗があった が，伊達の第 2 世代では減耗がなかった。ステージ IIIから V までに平均10-11\%の大きな減耗が 観察されたが，これは付属肢原基の形成と付属肢の分化の時期であった。な括ステージVと VI の間でも減耗率は高かったが (19\%)，雌個体の脱皮前に育児覇から幼体の離脱が観察されてい るので，育児寒に卯孚化幼体数が少ないことを直ちに幼体の死亡と結びつけることはできない。

餒化直後の幼体の形態：函館大森浜の $H$. japonicus の卵径は $350 \times 250 \mu \mathrm{m}$ であり, 伊達 の第 1 世代と第 2 世代の卵も大きさで違いはなかった。餒化した幼体の平均体長は $1.35 \mathrm{~mm}$ で

Table 6. Loss rate of embryos during development in Haustorioides munsterhjelmi of Shiomi-beach in mid-May, 1879. 陚川汐見海岸における H. munsterhjelmi の卵発生での 減耗率.

\begin{tabular}{ccccccc}
\hline $\begin{array}{c}\text { Stage of } \\
\text { development }\end{array}$ & $\begin{array}{c}\text { No. of } \\
\text { females } \\
\text { examined }\end{array}$ & $\begin{array}{c}\text { Mean body } \\
\text { length (mm) } \\
\pm \text { s. v. }\end{array}$ & $\begin{array}{c}\text { Mean brood } \\
\text { size } \pm \text { s. v. }\end{array}$ & $\begin{array}{c}\text { Brood size/ } \\
\text { body length } \\
\text { ratio }\end{array}$ & $\begin{array}{c}\text { Survival } \\
\text { rate } \% \text { \% }\end{array}$ & $\begin{array}{c}\text { Loss } \\
\text { rate } \\
(\%)\end{array}$ \\
\hline I & 14 & $13.50 \pm 0.67$ & $106.43 \pm 19.99$ & 7.88 & 100.00 & 0 \\
II & 12 & $13.50 \pm 0.58$ & $97.17 \pm 19.58$ & 7.19 & 91.30 & 8.70 \\
III & 12 & $13.48 \pm 0.68$ & $94.58 \pm 16.41$ & 7.02 & 88.87 & 11.13 \\
IV & 10 & $13.50 \pm 0.75$ & $77.27 \pm 15.36$ & 5.72 & 72.60 & 27.40 \\
V & 12 & $13.52 \pm 0.82$ & $62.42 \pm 20.74$ & 4.62 & 58.65 & 41.35 \\
\hline VI & 7 & $13.57 \pm 1.06$ & $54.57 \pm 5.77$ & 4.02 & 51.27 & 48.73 \\
\hline
\end{tabular}

Table 7. Less rate of eggs inter each stages of Haustorioides japonicus on the four sandybeaches, Hokkaido. 北海道の砂質海岸 4 か所における H. japonicus の卵発生での各ステージ間 の減耗率.

\begin{tabular}{|c|c|c|c|c|c|c|c|}
\hline Stage & Iwanai & Setana & Hakodate & Usu-1* & Usu-2** & Mean & Mukawa*** \\
\hline I - II & 11.84 & 8. 10 & 2.11 & 0.11 & 3.85 & 5.20 & 8.70 \\
\hline II —III & 8.18 & 7. 31 & 2.29 & 9.25 & 0 & 5.41 & 2.43 \\
\hline III - IV & 7.34 & 17.44 & 10.18 & 11.75 & 6.43 & 10.63 & 16.27 \\
\hline $\mathrm{IV}-\mathrm{V}$ & 8.70 & 1.12 & 3.15 & 18. 27 & 18.16 & 9.88 & 13.95 \\
\hline $\mathrm{V}-\mathrm{VI}$ & 17.83 & 22.34 & 18.96 & 33.91 & 4.22 & 19. 45 & 7.38 \\
\hline
\end{tabular}


ある。卵径の大きかった $(450 \times 350 \mu \mathrm{m}) \quad H$. munsterhjelmi の孵化直後の幼体は大きく 1.75 $\mathrm{mm}$ であった。両種とも第 1 触角は柄節を含めて 6 ないし 7 節からなり，第 2 触角は 8 ないし 9 節からなっていた。第 1 触角に鞭状副肢は存在しない。胸肢の分化は完全であるが成体に比 べて基節の拡張が小さくほっそりしていて各節の 剛毛も数少ない。腹肢の分化は不完全で分節 化まで至らず彫刻模様が観察された。H. japonicus の第 2 , 第 3 腹節側板の下部後縁は突出し ていた。第 1 尾肢と第 2 尾肢の付属葉はサーベル状を呈しょく発達していたが，第 3 尾肢の付 属葉は退化しており痕跡的である。尾節板は背面観で少し切れ込みがみられ成体のように隔合 してはいなかった。側面観で尾節板の末節は隆起していない。一方, H. munsterhjelmi の幼体 は第 3 節側板の下部後縁のみが少し突出していた。尾節板は背面観で成体のように少し切れ込 みがあって, 側面観で末端部の隆起が認められた。第 3 尾肢の付属葉は退化しているものの H. japonicus より大型であった (Fig. 3)。以上のように両種の粰化直後の幼体には, 同定に 必要とされる主要な形質が既に 部分的ながら備わっており種レベルの同定は餒化直後の幼体で 可能であった。

生長：岩内で 7 月上旬に捊化した体長 $1.35 \mathrm{~mm}$ の H. japonicus の幼体は翌春の 4 月下旬 までに成熟して産卵を始めたが，この第 1 世代は 300 日間に雌雄それぞれ $8.43 \mathrm{~mm}, 8.11 \mathrm{~mm}$ まで生長した (Fig. 4)。1 日あたりの生長率は雌で $24 \mu \mathrm{m}$, 雄で $23 \mu \mathrm{m}$ であった。一方, 5 月 上旬に誕生して 7 月上旬までに成熟した第 2 世代は，この90日間に雌雄でそれぞれ $5.00 \mathrm{~mm}$, $4.77 \mathrm{~mm}$ となった。1 日あたりの生長率は雌で $42 \mu \mathrm{m}$, 雄で $40 \mu \mathrm{m}$ であった。瀬棚で 4 月 上旬に粰化した体長 $1.35 \mathrm{~mm}$ の幼体は，翌春の 4 月下旬に成熟し産卵したが，この第 1 世代 は330日間に雌雄それぞれ $8.80 \mathrm{~mm}, 8.26 \mathrm{~mm}$ に達した。1日あたりの生長率は雌が $23 \mu \mathrm{m}$ ・ 雄が $21 \mu \mathrm{m}$ であった。一方，4 月下旬に誕生した第 2 世代は 95 日後の 7 月下旬に, 雌雄それ ぞれ $5.15 \mathrm{~mm}, 4.98 \mathrm{~mm}$ までに生長して, この間の生長率は雌で $40 \mu \mathrm{m} ・$ 雄で $38 \mu \mathrm{m}$ であ った。

函館で 6 月下旬に餒化した体長 $1.35 \mathrm{~mm}$ の幼体は翌春の 6 月上旬に成熟し産卵を始めるが, この第 1 世代は335日間に雌雄それぞれ 9.44-10.97 mm, 8.85-9.37 mm まで生長した。生長 率は 1 日あたり雌で 26-29 $\mu \mathrm{m}$ ・雄で 22-24 $\mu \mathrm{m}$ であった。当地で $H$. japonicus の世代交代

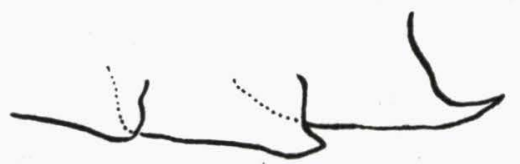

A

B

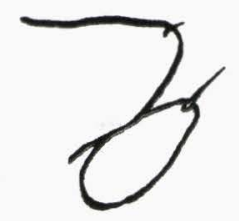

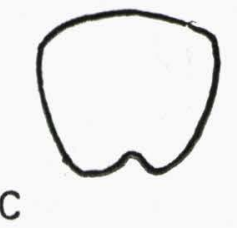

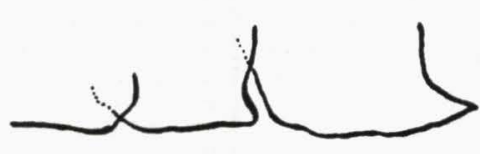

D

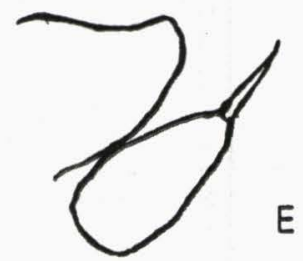

Fig. 3. Pleonal epimela 1-3, 3rd uropod and telson just after haching of Haustorioides japonicus (A-C) and $H$. munsterhjelmi (D, E). 躬化直後の $H$. japonicus と $H$. munsterhjelmi の第 1-3 腹節板. 第 3 尾肢 - 尾節板. 

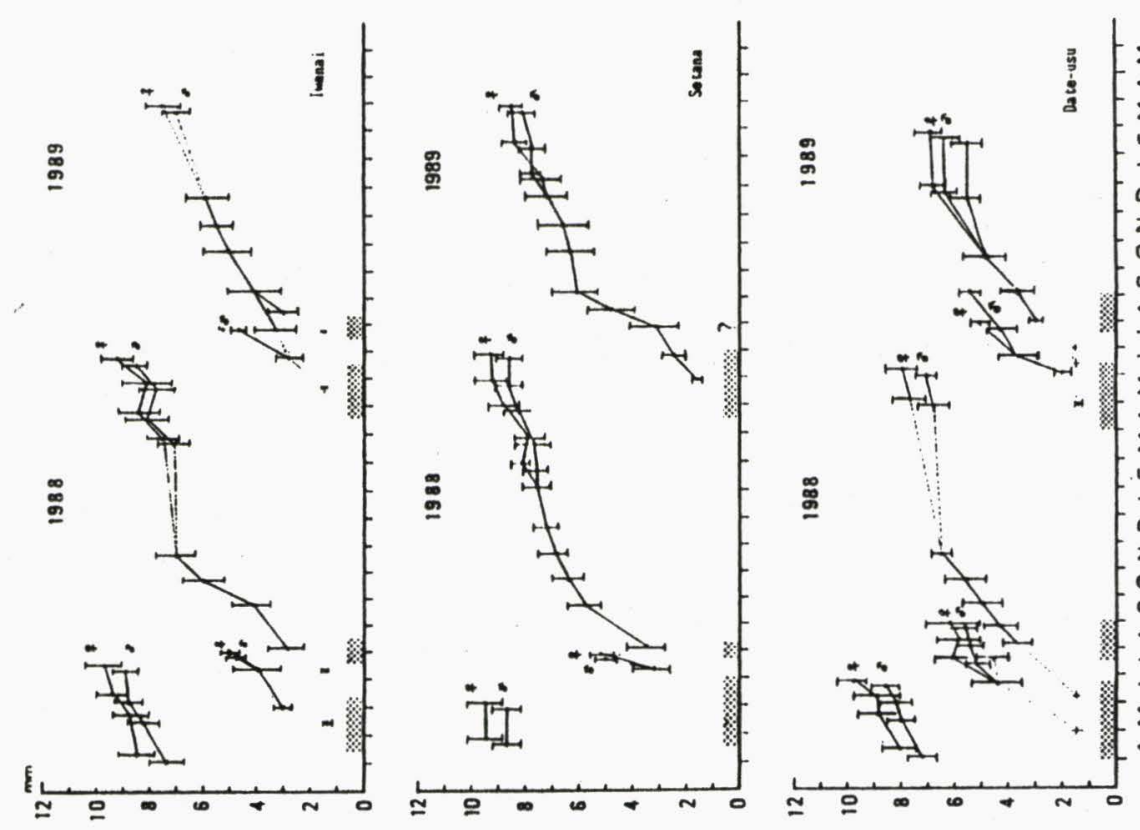

ई

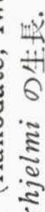

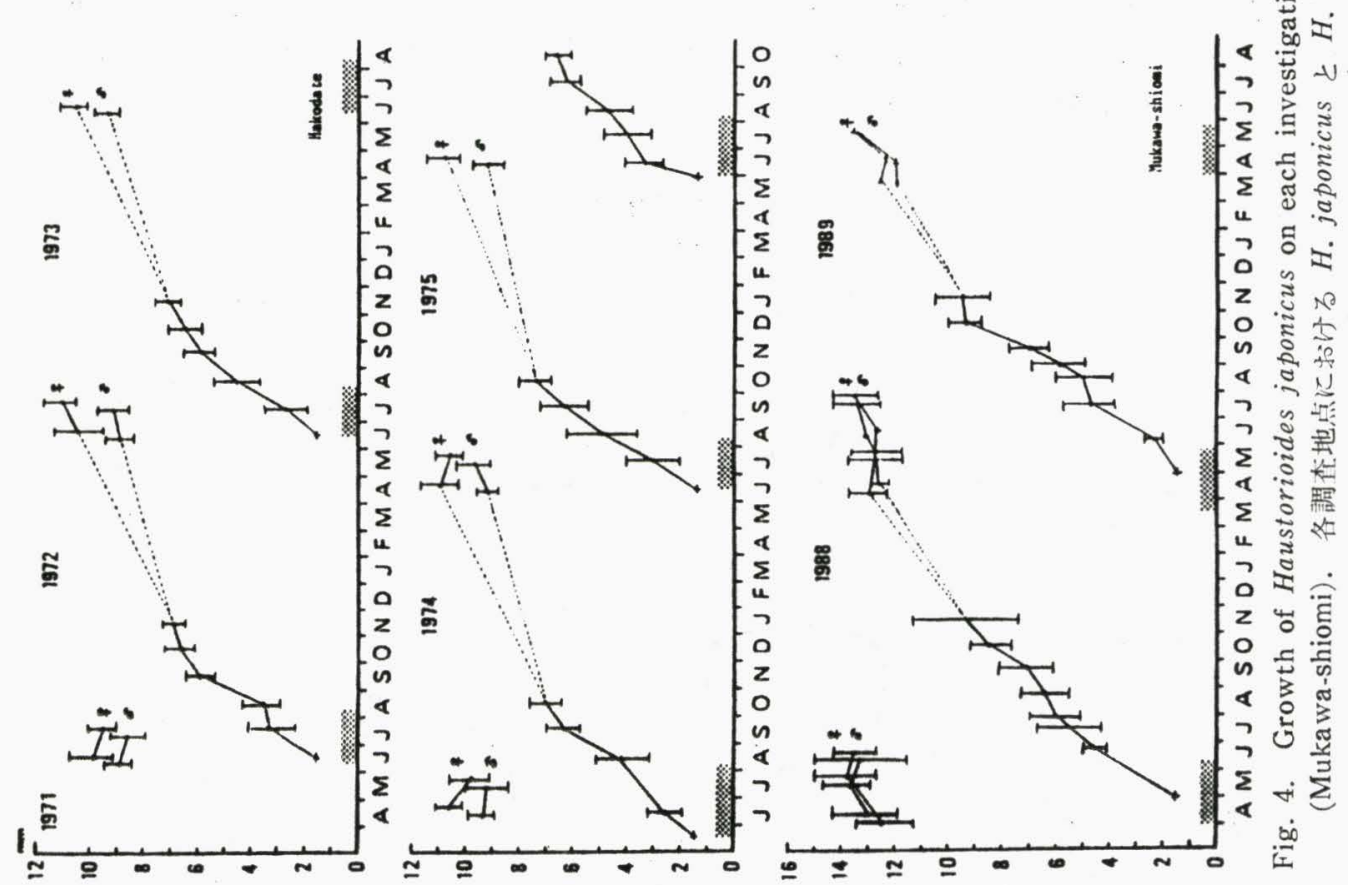


は年 1 世代であり第 2 世代の出現は観察されていない。伊達有珠で 7 月上旬に餒化した 体長 $1.35 \mathrm{~mm}$ の幼体は翌春の 4 月下旬までに成熟し産卵を始めたが，この第 1 世代は290日間に雌 雄それぞれ $7.66 \mathrm{~mm}, 6.79 \mathrm{~mm}$ までなった。1 日あたりの生長率は雌が $21 \mu \mathrm{m}$ ・雄が $18 \mu \mathrm{m}$ であった。一方， 5 月上旬に誕上した第 2 世代は 7 月下旬までの 75 日間に雌雄それぞれ 5.95 $\mathrm{mm}, 5.41 \mathrm{~mm}$ まで生長して, この間の生長率は雌で $61 \mu \mathrm{m}$ ・雄で $54 \mu \mathrm{m}$ であった。武川汐 見で 5 月上旬に餒化した体長 $1.50 \mathrm{~mm}$ の幼体は, 翌春の 4 月上旬までの 340 日間に雌雄それぞ れ 12.70-13.84 mm，12.75-13.78 mm まで生長して産卵を始めたが，この第 1 世代は 1 日あ たり雌雄とも 33-36 $\mu \mathrm{m}$ の生長率定記録した。当地で H. munsterhjelmi は年 1 世代であり, 第 2 世代の出現はなかった。

野外で H. japonicus の孵化した幼体が成熟して産卵するまでに必要とされた日数は, 今回 調查した地点では伊達有珠で最も短く75日間であった。この時点で雌の体長は 5. 0-6.0 mm, 雄 は 5.0-5.5 mm で小型であった。これに対して第 2 世代の出現することがなかった函館では, 産卵に至るまでに必要とされた日数は最も長く335日間であった。函館の雌は 9.9-10.9 mm, 雄 8.9-9.4 mm であり伊達有珠の第 2 世代の平均体長の1.6-1.8倍であった。成熟までの所要日数 が長いほど体長は大きくなる傾向があった。孵化してから 産卵直前までの 1 日あたり生長率は 有珠の第 2 世代で最も高く雌 $61 \mu \mathrm{m}$, 雄 $54 \mu \mathrm{m}$ であって, 函館では雌 26-29 $\mu \mathrm{m}$, 雄 22-24 $\mu \mathrm{m}$ で低かった。

生長を横軸に時間目盛りをとり縦軸に体の大きさをとってプロットすれば一般に S 型の生長 曲線が得られるが, その曲線は様々な数式で表現されてなかでも Logistic 式・Gompertzの 式·von Bertalanffy の式が代表的なるのである（松本 1978）。いま H. japonicus の生長を, Ricklefts のグラフ法によりこれらの式のあてはめの適否を比較検討した。この方法は生長曲線 を変換係数を用いることにより直線化して生長曲線の係数Kを求めようとするものである。こ の結果 Gompertz の生長方程式 $L=e^{-b e^{-k t}}$ が有効であり, それぞれの調査地における生長曲 線は次式で表現できた。

$\begin{array}{ll}\text { 岩内の第 } 1 \text { 世代 } & L=e^{-9.20 e^{-0.005(t-75)}} \\ \text { 瀬棚の第 } 1 \text { 世代 } & L=e^{-9.35 e^{-0.008(t-22)}} \\ \text { 函館の第 } 1 \text { 世代 } & L=e^{-11.13 e^{-0.005(t-70)}} \\ \text { 伊達の第 } 1 \text { 世代 } & L=e^{-7} \cdot 96 e^{-0.115(t-25)} \\ \text { 鴜川の第 } 1 \text { 世代 } L=e^{-13.45 e^{-0.008(t-92)}}\end{array}$

脱皮回数：端朋類の生長には脱皮をともない, 形態は少しずつ变化するが，なかでも 触角の節数の增加はよく知られている (SEXTON 1924)。Haustorioides japonicus と $H$. munsterhjelmi の生長と脱皮回数を知る目的で, 触角の節数と第 5 胸肢末端節の剛毛数の変化 を観察した (App. Table 1-5)。H. japonicus の第 5 胸肢末端節の岡毛数の変化のあることを 見つけたのは著者である。両種とも 1 回の脱皮により触角の節数は第 1 触角あるいは第 2 触角 で 1 節の増加がみられた。また第 5 胸肢末端節は剛毛は体長 $2 \mathrm{~mm}$ 位の幼体と成体では不規則 であったが，抢抢よそ1ないし 2 対づつ増加していた。飼育観察より函館の大森浜の H. japonicus は, この二つの形質により体長 $9.5 \mathrm{~mm}$ の雄で 9 回の脱皮が認められた。雌は産卵し幼 体を捊化させた後さらに 2 回の脱皮を行い, なかには 8 月上旬に死亡するまでに通算して 13 回 目の脱皮した個体も25\%ほどいた。脱皮間隔は水温 $20.7 \pm 1.3^{\circ} \mathrm{C}$ で成体雌では13-14日間, 雄 
Table 8. Difference of the segments number of antenles, and the setose of 5 th pereopods teminal segment of Haustorioides japonicus in two sampling station. 二つの調查地点 に打ける H. japonicus の触角の節数と第 5 歩脚末端節岡毛数の相違.

\begin{tabular}{|c|c|c|c|c|c|}
\hline $\begin{array}{l}\text { Sampling } \\
\text { station }\end{array}$ & $\begin{array}{l}\text { Body length } \\
\qquad(\mathrm{m} \mathrm{m})\end{array}$ & $\begin{array}{l}\text { Segments of } \\
\text { 1st antenna }\end{array}$ & $\begin{array}{l}\text { segments of } \\
\text { 2nd antenna }\end{array}$ & $\begin{array}{l}\text { Setose of } 5 \text { th } \\
\text { pereopods } \\
\text { terminal segment }\end{array}$ & Sex \\
\hline \multirow{2}{*}{$\begin{array}{c}\text { Omori-beach, } \\
\text { Hakodate }\end{array}$} & $9.00 \pm 0.45$ & $11-12$ & $13-15$ & $40-58$ & male \\
\hline & $10.34 \pm 0.37$ & $11-12$ & $13-15$ & $26-30$ & female \\
\hline \multirow{4}{*}{$\begin{array}{l}\text { Usu-beach, } \\
\text { Date }\end{array}$} & $7.41 \pm 0.46^{*}$ & $9-10$ & $11-12$ & $22-36$ & male \\
\hline & $7.99 \pm 0.57^{*}$ & $9-10$ & $11-12$ & $14-18$ & female \\
\hline & $5.23 \pm 0.19^{* *}$ & $9-10$ & $10-11$ & $20-36$ & male \\
\hline & $5.96 \pm 0.34^{* *}$ & $9-10$ & $10-11$ & $14-16$ & female \\
\hline
\end{tabular}

* 1st generation, ** 2nd generation

では15-17日間であった。第 5 胸肢末端節の剛毛数は繁殖期を迎えた時点で性差が明瞭に認めら れ, 雄で 40-58本, 雌では 26-30本であった。この剛毛数の違いは外形より雌雄を範便に区別す るときに第 2 顎脚の形態的差異とともに有効なものであった。

伊達の H. japonicus では， 5 月上旬に誕生して 2 か月半で成体に達した小型な第 2 世代は, 雌雄とも触角節数は函館に産するものより 2-3節少く, 第 5 胸肢末端節の剛毛数も Table 8 に 示したように雄は20-36本, 雌は14-18本とそれぞれ函館の個体群よりも少なかった。また 7 月上 旬に搫化して翌年 4 月下旬に成体になった第 1 世代は，第 2 世代よりも体長は大きいが第 1 触 角の節数と第 5 胸肢末端節の剛毛数は同じで, 第 5 触角の節数は 1 節多かった。しかし函館に生 息する個体群よりも触角の節数, 第 5 胸肢末端節の剛毛数はいずれも少ない。脱皮回数は伊達の 第 1 世代で7-8回，第 2 世代で6-7回であって隶館の H. japonicus より1-3回少ない。H. munsterhjelmi では10回の脱皮が観察されたが，脱皮間隔は水温 $19.7 \pm 1.5^{\circ} \mathrm{C}$ で成体雌では19-21 日間, 雄で22-23日間であった。

論

議

端脚類をはじめとするフクロエビ類の成体雌は, 歩脚の底節付近に発達する数対の覆卵葉か ら形成される育児囊を所有している。このため卵および幼体の高い保護機能が期待されるので, ナミノリソコェビ科端脚類についてこの点をまず検討した。育児賈内の卵隇耗に関しては, FISH (1975) が Bathyporeia pilosa で捊化直前のステージVで27\%の減耗を報告した。WILLIAMS (1978)は Talitrus saltor のステージVで27.2\%の死亡率を観察しており，この值はVLASBLOM (1969) によって調べられた Marinogammarus marinus の21.3\%および37.3\%と泳ほ類似した ものであったと述べている。一方, SALVAT (1967) は B. pelagica と B. sarsi で減耗のな かったことを報告している。

今回調べた Haustorioides japonicus で, ステージVまでに函館では18\%, 岩内で 36\%, 瀬 棚で34\%の減耗をそれぞれ観察した。さらに伊達の第 1 世代で39\%の減耗を，そして第 2 世代 で28\%の減耗を観察したが, これらの数值はツノヒゲソコェビ科の Bathyporera spp. の減耗 
率よりも概ね高かった。ナミノリソコエビ科をはじめとする大多数の 端脚類では体が左右に側 偏しているのに, ッノヒゲソコエビ科は背腹に圧縮された特異な形態をしており，卵径はやや 大きく産卵数が少ないことが特徴的であって，この繁殖様式の違いがナミノリソュエビ科（小 卵，多産）の減耗率の高さとの大きな違いとなっているように考学られた。

前述した他科端脚類の隇耗率の低さは, 育児囊の存在による「保育機能=高い生残率」と結び つけて考えられる。しかし H. japonicus の観察では, 孵化直前のテージVまでの卵生残率は61$82 \%$ で各調査地でばらつきがあり (平均 $68.9 \%$ ), この值は育児䧶をもつことから期待されるほ どの高い生残率ではなかった。CROKER (1968) は Neohaustorius schmitzii で, また SHEADER \& CHIA (1970) は Enlimnogammarus obtusatus と E. finmarchicus で, それぞれ一度放出 された幼体が育児囊に再び㞍る行動を観察している。青木 (1989) はョコエビ類に近縁なワレ カラ類で「子守行動」を観察して, 移動能力に劣り限られた場所をすみかとするるのに拈いて 保護の発達する傾向のあったことを報告した。また過去の報告より広く端脚類の幼体の保護を 分析して (青木 1990), 母親の保護は自由生活から基質に把握する生活に意向する方向への発 達と, 自由生活から寄生への生活に移行する方向への発達がみられるといら。調査した $H$. japonicus と H. munsterhjelmi ではこれらの育児行動は観察されず, ナミノリソコエビ科端脚 類の卵ならびに幼体の保育能力は育児囊の保有にもかかわらずやや貧弱であった。

な拉, 一腹産卵数が少ない端脚類にあってナミノリソコエビ科の種は珍しく多産であること が特色で (上平, 印刷中), ツノヒゲソコェビ科の Bathyporeia をはじめとして多くの砂中生 活型端脚類が少産の繁殖戦略 (K-戦略) であるのに対して, H. japonicus と H. munsterhjelmi は逆方向の多産的繁殖様式, すなわち r-戦略をとっているように観察されるが, この点につい ては匑化した幼体が繁殖期を迎えるまでの生残率を, 詳細に観察したらえで論議することとし 今後の研究課題としたい。

(1) 北海道南部の砂質海岸に生息していたナミノリソコエビ科端脚類の発生と生長を調べた。 Haustorioides japonicus と H. munsterhjelmi の産卵は成熟した雌の覆卵葉からなる育児露中 になされる。餒化した幼体は育児囊から離脱したのち直ちに底生生活に入る。幼体は直達発生 で全く浮游生活期がない。このため各調查地の潮間帯と垔潮間帯の 浅海域で閉鎖的な生息地固 体群をなしていると推察された。

(2) 二種の捊化直後の幼体は, 成体と同じく腹節側板と第 3 尾肢で形態的相違が 明瞭に認め られ，種レベルでの同定が可能であった。

(3) H. japonicus の生長は各生息地で違いがあり, 成体になるまでの生長率は伊達有珠で 1 日あたり 54-61 $\mu \mathrm{m}$ で最も大きく, 函館で 22-29 $\mu \mathrm{m}$ で最も小さかった。早く成熟する個体注 ど生長率が高く, また成体は小型であった。生長は Gompertz の方程式で表現することができ た。

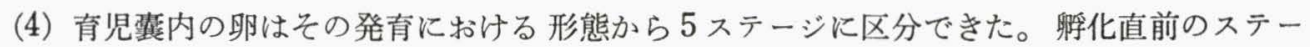
ジVまでに H. japonicus の卵減耗率は17.7-39.3\%であって，H. munsterhjelmi では41.4\% であった。 
(5) H. japonicus の脱皮間隔は水温 $21^{\circ} \mathrm{C}$ で, 成体雌では13-14日間, 雄で15-17日間であっ た。飼育観察より躬化してから成体になるまでに第 1 世代で8-9回の脱皮がなされ，その回数は 各調査地で多少の違いが認められた。また死亡するまでに最高で 13 回の脱皮が 観察された。 H. munsterhjelmi の脱皮間隔は水温 $20^{\circ} \mathrm{C}$ で, 成体雌では19-22日間, 雄で22-23日であった。 両種とも雄が雌よりもわずかながら脱皮間隔は長かった。

\section{参 考 文 献}

青木優和, 1989. ワレカラ類 (Amphipoda : Caprellidae) にみられる“子守行動”の意義について，日本甲 殸類学会第27回大会講演要旨 No. 8.

一， 1990. 端脚類にみられる有房を出た幼体に対する母親の保護にについて，甲殼類の水産・分類・ 生態に関するシンポジウム報告, 第 1 回千葉県立中央博物館自然誌シンポジウム講演要旨.

CROKER, R.A., 1968. Return of juveniles to the marsupium in the amphipoda Neohaustorius schmizii Bousfield. Crustaceana, 14: 215.

Fish, J.D., 1975. Development, hatching and brood size in Bathyporeia pilosa and B. pelagica (Crustacea; Amphipoda). J. mar. biol. Ass. U.K. 55 : 357-386.

上平幸好, 1990. 北海道南部の砂質海岸に生息するナミノリソコエビ科端脚類の生活史. 甲殼類の研究. No. $18,53-70$.

(印刷中)，北海道南部の砂質海岸に生息するナミノリソコェビ科端脚類の 繁殖生態. 甲殼類の研 究. No. 19,

松本忠夫, 1978. 成長. 117-133，松本忠夫・中村方子共著「動物の物質経経法」 $153 \mathrm{pp}$ ，北沢右三ほか編 「生態学研究法講座 23$\rfloor$, 共立出版.

Salvat, B., 1967. La macrofauna carcinologique endogie des sediments meubles intertidaux, Ethalogie, bionomie et cycle biologique. In Fish, J. D. (1975). J. mar. biol. Ass. U.K., $55: 357-368$.

Sexton, E.W., 1924. The moulting and growth-stages of Gammarus, with descriptions of normals and intersexes of G. chevreuxi. Ibid., $8: 340-401$.

Sheader, M. \& Chia, F.S., 1970. Development, fecundity and breeding behavior of the amphipod, Marinogammarus obtusatus. Ibid., 50 : 1079-1099.

Vlasblom, A.G., 1969. A study of a population of Marinogammarus marinus (Leach) in the Oosterschelde, Neth. J. Sea Res. 4: 317-338.

Williams, J.A., 1978. The annual patern of reproduction of Talitridae saltator (Crustacea: Amhipoda: Talitridae). J. Zool. Lond. 184: 231-244. 
Appendix 1A. Changes of the segmental numbers of antenules, and the setose of 5th pereopod's terminal segment of Haustorioides japonicus in Omori-beach, Hakodate. 函館大森浜に生息 する H. japonicus の生長にともなう触角節数と第歩 5 脚末端節剛毛数の変化.

\begin{tabular}{|c|c|c|c|}
\hline $\begin{array}{l}\text { Body length } \\
\qquad(\mathrm{mm})\end{array}$ & $\begin{array}{l}\text { Segments of } \\
\text { 1st antenna }\end{array}$ & $\begin{array}{l}\text { Segments of } \\
2 \mathrm{ng} \text { antenna }\end{array}$ & $\begin{array}{l}\text { Setose of } 5 \text { th pereopod's } \\
\text { ternimal segment }\end{array}$ \\
\hline 1.35 & $6(\text { III }+2+i)^{*}$ & $8(V+2+i)^{*}$ & 2 \\
\hline 1.50 & $6($ III +3$)$ & $8(V+3)$ & 2 \\
\hline 2.00 & $7($ III $+3+i)$ & $9(V+3+i)$ & 6 \\
\hline 3.50 & $8($ III $+4+i)$ & $10(V+4+i)$ & 6 \\
\hline 3.00 & $8($ III $+4+i)$ & $11(V+5+i)$ & 8 \\
\hline 3.50 & $9($ III $+5+i)$ & $12(V+6+i)$ & 10 \\
\hline 4. 00 & $9($ III $+5+\mathrm{i})$ & $12(\mathrm{~V}+6+\mathrm{i})$ & 12 \\
\hline 4.50 & $10($ III $+6+i)$ & $12(V+6+i)$ & 14 \\
\hline 5.00 & $10($ III $+6+i)$ & $12(V+6+i)$ & 14 \\
\hline 5.50 & $10($ III $+6+i)$ & $12(\mathrm{~V}+7)$ & 16 \\
\hline 6.00 & $11($ III $+7+i)$ & $12(V+6+i)$ & 16 \\
\hline 6.50 & $11($ III $+7+\mathrm{i})$ & $12(\mathrm{~V}+6+\mathrm{i})$ & 18 \\
\hline 7.00 & $11($ III $+7+i)$ & $13(V+7+i)$ & 18 \\
\hline 7.50 & $11($ III $+7+\mathrm{i})$ & $13(V+7+i)$ & 20 \\
\hline 8.00 & $11($ III $+7+i)$ & $13(\mathrm{~V}+7+\mathrm{i})$ & 20 \\
\hline 8.50 & $11($ III $+7+\mathrm{i})$ & $13(V+7+i)$ & 42-58 male \\
\hline 9.00 & $11(\mathrm{III}+7+\mathrm{i})$ & $15(V+9+i)$ & 40-58 male \\
\hline 9.50 & $11($ III +8$)$ & $15(V+10)$ & 40-48 male \\
\hline 9.50 & $11($ III $+8+i)$ & $15(\mathrm{~V}+10)$ & 26 female \\
\hline 10.00 & $11($ III +8$)$ & $15(V+9+i)$ & $26-28$ female \\
\hline 10.50 & $12($ III +9$)$ & $15(\mathrm{~V}+10)$ & $26-28$ female \\
\hline 10.75 & $12($ III +9$)$ & $15(V+10)$ & $28-30$ female \\
\hline
\end{tabular}

* peduncles + large fellagelum + small fellagelum

Appendix 1B. The morphological characteristic changes revealed through the study of Haustorioides japonicus reared, of which hatched from ovigerous female collected from Omori-beach, Hakodate. 函館大森浜で採集した H. japonicus の抱卵雌より餒化し た幼体飼育より明らかとなった形質の変化.

\begin{tabular}{|c|c|c|c|c|}
\hline $\begin{array}{l}\text { Body } \\
(\mathrm{m} \mathrm{m})\end{array}$ & $\begin{array}{l}\text { length } \\
\text { Days }\end{array}$ & $\begin{array}{l}\text { Segments of } \\
\text { 1st antenna }\end{array}$ & $\begin{array}{l}\text { Segments of } \\
\text { 2nd antenna }\end{array}$ & $\begin{array}{l}\text { Setose of } 5 \text { th pereopod's } \\
\text { ternimal segment }\end{array}$ \\
\hline 1.35 & 1 & $6(\text { III }+3)^{*}$ & $8(V+2+i)^{*}$ & 2 \\
\hline 1.45 & 3 & $6(\mathrm{III}+3)$ & $8(V+3)$ & 2 \\
\hline 1.50 & 4 & $6(\mathrm{III}+3)$ & $8(V+3)$ & 2 \\
\hline 1.75 & 10 & $7(\mathrm{III}+4)$ & $9(V+3+i)$ & 6 \\
\hline 2.15 & 15 & $7($ III +4$)$ & $9(\mathrm{~V}+3+\mathrm{i})$ & 6 \\
\hline 2.40 & 20 & $8(\mathrm{III}+5)$ & $10(V+4+i)$ & 8 \\
\hline 2.60 & 25 & $8(\mathrm{III}+5)$ & $10(V+4+i)$ & 8 \\
\hline 2.80 & 37 & $8($ III +5$)$ & $11(V+5+i)$ & $8+$ \\
\hline 3.55 & 45 & $9($ III $+5+\mathrm{i})$ & $11(V+5+i)$ & $8+$ \\
\hline \multirow[t]{2}{*}{4.50} & 63 & $10($ III $+6+i)$ & $12(V+6+i)$ & $8+$ \\
\hline & 78 & $10($ III $+6+i)$ & $12(V+6+i)$ & $8+$ \\
\hline 4.50 & 100 & $10($ III $+6+i)$ & $12(V+6+i)$ & $10+$ \\
\hline
\end{tabular}

* peduncles + large flagellum + small flagellum 
Appendix 2. Changes of the segmental numbers of antenules, and the setose of 5th pereopod's terminal segment of Haustorioides japonicus (1st generation) in Usubeach, Date. 伊達有珠に㧊ける H. japonicus の第 1 世代の生長にともなら触角節数と 第 5 脚末端節剛毛数の変化.

\begin{tabular}{|c|c|c|c|}
\hline $\begin{array}{l}\text { Body length } \\
\qquad(\mathrm{mm})\end{array}$ & $\begin{array}{l}\text { Segments of } \\
\text { 1st antenna }\end{array}$ & $\begin{array}{l}\text { Segments of } \\
\text { 2nd antenna }\end{array}$ & $\begin{array}{l}\text { Setose of } 5 \text { th pereopod's } \\
\text { ternimal segment }\end{array}$ \\
\hline 1.35 & $6(\text { III }+2+i)^{*}$ & $8(V+2+i)^{*}$ & 1 \\
\hline 2.00 & $7($ III $+3+i)$ & $8(V+2+i)$ & 7 \\
\hline 2.50 & $7($ III +4$)$ & $9(\mathrm{~V}+4)$ & 7 \\
\hline 3.00 & $7($ III +4$)$ & $10(V+5)$ & 9 \\
\hline 3.50 & $8($ III +5$)$ & $11(V+6)$ & 10 \\
\hline 4.00 & $8(I I I+5)$ & $11(V+6)$ & 12 \\
\hline 4.50 & $9(\mathrm{III}+5+\mathrm{i})$ & $11(V+6+i)$ & 13 \\
\hline 5.00 & $6($ III +6$)$ & $11(\mathrm{~V}+6)$ & 14 \\
\hline 5.50 & $9(\mathrm{III}+5+\mathrm{i})$ & $11(v+6)$ & 16 male \\
\hline 6.00 & $9($ III $+5+i)$ & $12(V+6)$ & 16 male \\
\hline 6.50 & $10(\mathbb{I I}+6+\mathrm{i})$ & $12(\mathrm{~V}+7)$ & $15-16$ male \\
\hline 7.00 & $11(\mathrm{III}+7+\mathrm{i})$ & $12(V+7)$ & $16-17$ male \\
\hline 7.50 & $10(\mathrm{III}+7)$ & $12(V+7)$ & 30 male \\
\hline 8.00 & $10(\mathrm{III}+7)$ & $12(V+7)$ & $27-30$ male \\
\hline 8.50 & $10($ III $+6+i)$ & $12(V+7)$ & 36 male \\
\hline 8.75 & $10($ III $+6+i)$ & $12(V+7)$ & 40 male \\
\hline 5.50 & $9(\mathrm{II}+5+\mathrm{i})$ & $11(V+6)$ & 13 female \\
\hline 6.00 & $9(\mathrm{II}+6)$ & $11(V+6)$ & 14 female \\
\hline 7.00 & $10($ III $+6+i)$ & $12(V+7)$ & 12-14 female \\
\hline 7.50 & $10(\mathrm{II}+6+\mathrm{i})$ & $12(V+7)$ & 16 female \\
\hline 8.00 & $10($ III $+6+i)$ & $12(V+7)$ & 20 female \\
\hline 8.50 & $10($ III $+6+i)$ & $12(V+7)$ & $18-20$ female \\
\hline 9.00 & $10($ III +7$)$ & $12(V+7)$ & 22 female \\
\hline 9.50 & $10(\mathrm{III}+6+\mathrm{i})$ & $12(\mathrm{~V}+7)$ & $18-22$ female \\
\hline 10.00 & $10($ III +7$)$ & $12(V+7+i)$ & $16-24$ female \\
\hline 10.50 & $12($ III +9$)$ & $15(V+10)$ & 26 female \\
\hline
\end{tabular}

* peduncles + large flagellum + small flagellum 
Appendix 3. Changes of the segmental numbers of antenules, and the setose of 5 th pereopod's terminal segment of Haustorioides japonicus (2nd generation) in Usu beach, Date. 伊達有珠における H. japonicus の第 2 世代の生長にともなら触角節数と 第 5 歩脚末端剛毛数の変化.

\begin{tabular}{|c|c|c|c|}
\hline $\begin{array}{l}\text { Body length } \\
\qquad(\mathrm{mm})\end{array}$ & $\begin{array}{l}\text { Segments of } \\
\text { 1st antenna }\end{array}$ & $\begin{array}{l}\text { Segments of } \\
\text { 2nd antenna }\end{array}$ & $\begin{array}{l}\text { Setose of } 5 \text { th pereopod's } \\
\text { ternimal segment }\end{array}$ \\
\hline 1.35 & $6(\mathrm{III}+2+\mathrm{i})^{*}$ & $8(V+2+i) *$ & 1 \\
\hline 2.00 & $7($ III $+3+\mathrm{i})$ & $8(V+2+i)$ & 1 \\
\hline 2.50 & $7($ III $+3+\mathrm{i})$ & $9(V+4)$ & 5 \\
\hline 2.75 & $7($ III $+3+i)$ & $9(V+3+i)$ & 5 \\
\hline 3.00 & $7($ III +4$)$ & $10(V+4+i)$ & 6 \\
\hline 3.25 & $8($ III $+4+i)$ & $9(\mathrm{~V}+4)$ & 6 \\
\hline 3.50 & $8($ III $+4+\mathrm{i})$ & $10(V+4+i)$ & 7 \\
\hline 4.00 & $8($ III $+4+i)$ & $10(V+5)$ & 7 \\
\hline 4.25 & $9(\mathrm{III}+5+\mathrm{i})$ & $10(V+5)$ & 8 \\
\hline 4.50 & $9(\mathrm{III}+5+\mathrm{i})$ & $11(V+6)$ & 18 male \\
\hline 4.75 & $9($ III $+5+\mathrm{i})$ & $11(V+6)$ & 19 male \\
\hline 5.00 & $9(\mathrm{II}+5+\mathrm{i})$ & $11(V+6)$ & 20 male \\
\hline 5.25 & $9($ III $+5+i)$ & $11(V+6)$ & 24 male \\
\hline 5.50 & $9($ III $+5+\mathrm{i})$ & $11(V+6)$ & 26 male \\
\hline 5.75 & $10($ III $+6+i)$ & $12(\mathrm{~V}+7)$ & 28 male \\
\hline 6.00 & $10($ III $+6+i)$ & $12(V+6+i)$ & 34 male \\
\hline 4.50 & $9($ III $+5+\mathrm{i})$ & $10(V+5+i)$ & 11 female \\
\hline 5.00 & $9($ III $+5+i)$ & $11(V+6)$ & $11-13$ female \\
\hline 5.25 & $9(\mathrm{III}+5+\mathrm{i})$ & $11(V+6)$ & 11 female \\
\hline 5.50 & $9($ III $+5+\mathrm{i})$ & $11(V+6)$ & 11 female \\
\hline 5.75 & $9(\mathrm{III}+5+\mathrm{i})$ & $11(V+6)$ & 12 female \\
\hline 6.00 & $10($ III $+6+i)$ & $11(V+6)$ & 15 female \\
\hline 6.25 & $10(\mathrm{III}+6+\mathrm{i})$ & $11(V+6)$ & 15 female \\
\hline 6.50 & $10($ III $+6+i)$ & $12(V+7)$ & $14-15$ female \\
\hline 6.75 & $10(I I I+6+i)$ & $12(V+7)$ & 16 female \\
\hline 7.00 & $10(\mathrm{III}+6+\mathrm{i})$ & $12(V+6+i)$ & 17 female \\
\hline
\end{tabular}

* peduncles + large flagellum + small flagellum 
Appendix 4. Changes of the segmental numbers of antenules, and the setose of 5 th pereopod's terminal segment of Haustorioides munsterhjelmi in Shiomi-beach, Mukawa. 武鳥川町汐見浜における H. munsterhjelmi の生長にともなら触角節数と第 5 歩脚末端節岡毛数の変化.

\begin{tabular}{|c|c|c|c|}
\hline $\begin{array}{l}\text { Body length } \\
\qquad(\mathrm{mm})\end{array}$ & $\begin{array}{l}\text { Segments of } \\
\text { 1st antenna }\end{array}$ & $\begin{array}{l}\text { Segments of } \\
\text { 2nd antenna }\end{array}$ & $\begin{array}{l}\text { Setose of } 5 \text { th pereopod's } \\
\text { ternimal segment }\end{array}$ \\
\hline 1.75 & $6(\mathrm{III}+3)^{*}$ & $9(\mathrm{~V}+3+\mathrm{i})^{*}$ & 0 \\
\hline 2.00 & $7(\mathrm{III}+3+\mathrm{i})$ & $11(V+4+i)$ & 1 \\
\hline 2.50 & $8(I I I+4+i)$ & $10(V+5)$ & 1 \\
\hline 3.00 & $8($ III +5$)$ & $10(V+5)$ & 1 \\
\hline 3.50 & $9(I I I+5+i)$ & $11(V+6)$ & 1 \\
\hline 4.00 & $9($ III $+5+i)$ & $11(V+6)$ & 1 \\
\hline 4.50 & $9($ III $+5+i)$ & $11(V+6)$ & 2 \\
\hline 5.00 & $10($ III $+6+i)$ & $12(V+7)$ & 3 \\
\hline 5.50 & $11($ III $+7+\mathrm{i})$ & $12(V+7)$ & 5 \\
\hline 6.00 & $11($ III $+7+\mathrm{i})$ & $13(V+8)$ & 4 \\
\hline 6.50 & $11($ III $+7+\mathrm{i})$ & $13(V+8)$ & 3 \\
\hline 7.00 & $12($ III $+8+i)$ & $14(V+9)$ & 6 \\
\hline 7.50 & $11($ III +8$)$ & $14(V+8+i)$ & 7 \\
\hline 8.00 & $12($ III +9$)$ & $15(\mathrm{~V}+10)$ & $8-10$ \\
\hline 8.50 & $12($ III +9$)$ & $14(V+9)$ & 8 \\
\hline 9.00 & $12($ III +9$)$ & $15(V+10)$ & 8 male \\
\hline 9.50 & $12($ III +9$)$ & $14(V+9)$ & 7-8 male \\
\hline 10.00 & $13($ III $+9+i)$ & $15(\mathrm{~V}+10)$ & 8 male \\
\hline 10.50 & $13($ III +10$)$ & $15(\mathrm{~V}+10)$ & 8-12 male \\
\hline 11.00 & $13($ III +10$)$ & $15(\mathrm{~V}+10)$ & 8-12 male \\
\hline 11.50 & $12($ III +9$)$ & $14(\mathrm{~V}+9)$ & 6-12 male \\
\hline 12.00 & $13($ III $+9+\mathrm{i})$ & $14(V+9)$ & 12 male \\
\hline 12.50 & $13($ III $+9+i)$ & $15(V+10)$ & $11-12$ male \\
\hline 13.00 & $13(\mathrm{III}+10)$ & $15(\mathrm{~V}+10)$ & 9-12 male \\
\hline 13.50 & $13($ III +10$)$ & $15(\mathrm{~V}+10)$ & 10-12 male \\
\hline 14.00 & $14($ III +11$)$ & $16(\mathrm{~V}+11)$ & 10-12 male \\
\hline 14.50 & $14($ III $+10+i)$ & $15(V+10)$ & $10-12$ male \\
\hline 9.00 & $11($ III +8$)$ & $13(V+8)$ & 5 female \\
\hline 9.50 & $12($ III $+8+i)$ & $14(V+9)$ & 6 female \\
\hline 10.00 & $12($ III $+9+i)$ & $15(V+10)$ & 6 female \\
\hline 10.50 & $11($ III +8$)$ & $14(V+9)$ & 6 female \\
\hline 11.00 & $12(\mathrm{III}+80+\mathrm{i})$ & $14(V+9)$ & 7 female \\
\hline 11.50 & $12($ III +9$)$ & $14(V+9)$ & 7 female \\
\hline 12.00 & $12($ III +9$)$ & $15(V+10)$ & 7 female \\
\hline 12.50 & $13($ III +10$)$ & $15(\mathrm{~V}+10)$ & $7-10$ female \\
\hline 13.00 & $14($ III $+10+i)$ & $14(V+9)$ & $9-10$ female \\
\hline 13.50 & $14($ III $+10+i)$ & $15(V+10)$ & 8-10 female \\
\hline 14.00 & $14($ III $+10+\mathrm{i})$ & $15(V+10)$ & 8-12 female \\
\hline 14.50 & $14($ III $+10+i)$ & $15(V+10)$ & 10-12 female \\
\hline 15.00 & $14($ III $+10+i)$ & $15(V+10)$ & 9-12 female \\
\hline
\end{tabular}

* peduncles +large flagellum + small flagellum 

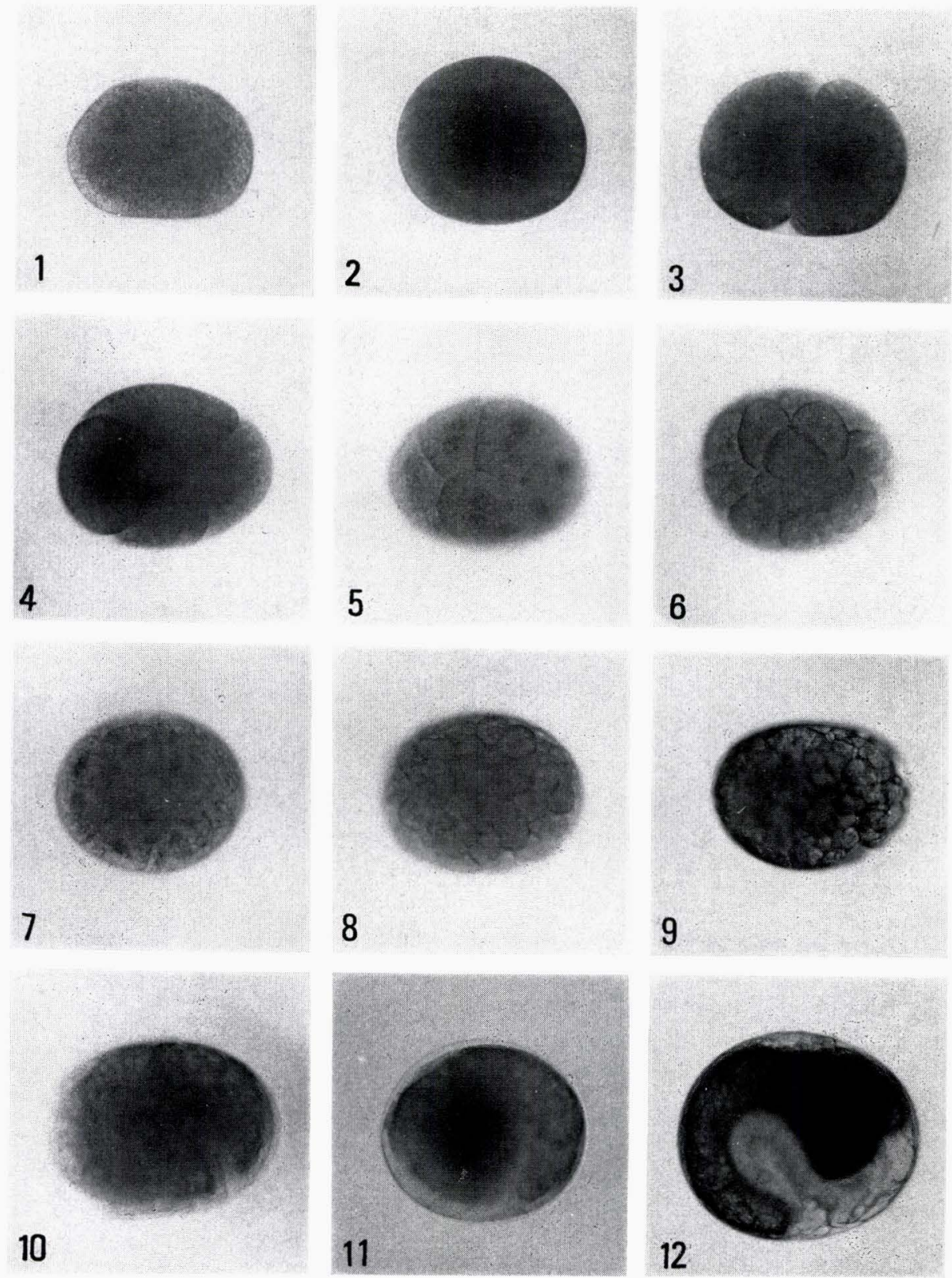

Plate I. Development of Haustorioides japonicus. 1. Unfertilized egg $325 \times 225 \mu \mathrm{m}$. 2. Fertilized egg $350 \times 250 \mu \mathrm{m}$. 3. 2-celled stage. 4. 4-celled stage. 5. 8-celled stage. 6. 16-celled stage. 7. 16-celled stage $375 \times 325 \mu \mathrm{m}$. 8 . Germinal disc forming stage $375 \times 325 \mu \mathrm{m}$. 9. Germinal disc forming stage $400 \times 325 \mu \mathrm{m}$. 10. Caudal furrow forming stage $400 \times 325 \mu \mathrm{m}$. 11. Caudal furrow forming stage $450 \times 400 \mu \mathrm{m}$. 12. Dorsal organ forming stage $475 \times 400 \mu \mathrm{m}$. 


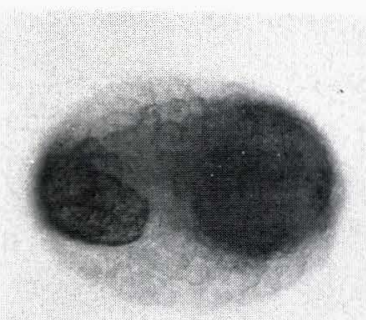

13

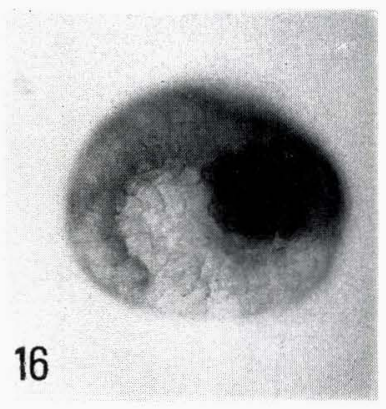

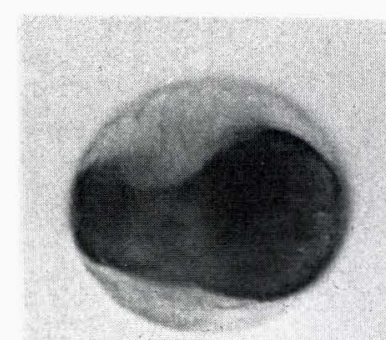

14

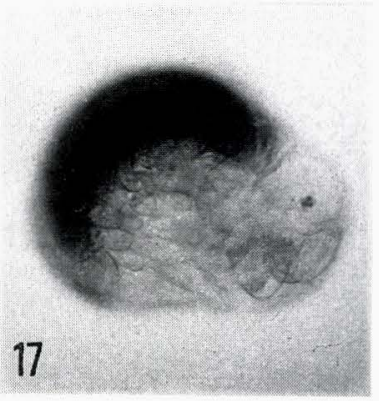

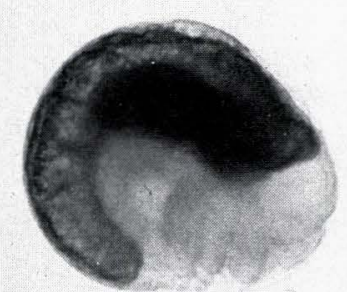

15

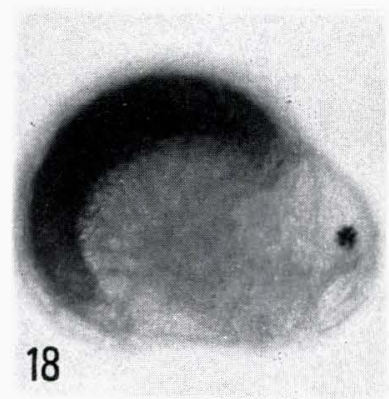

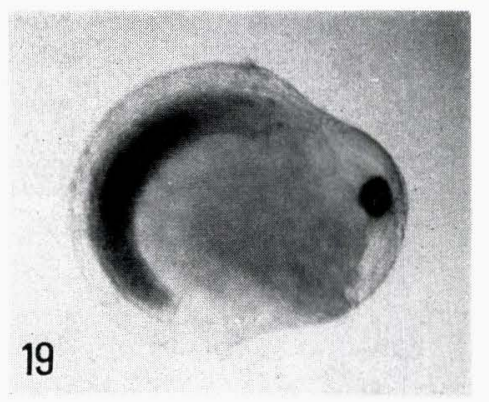
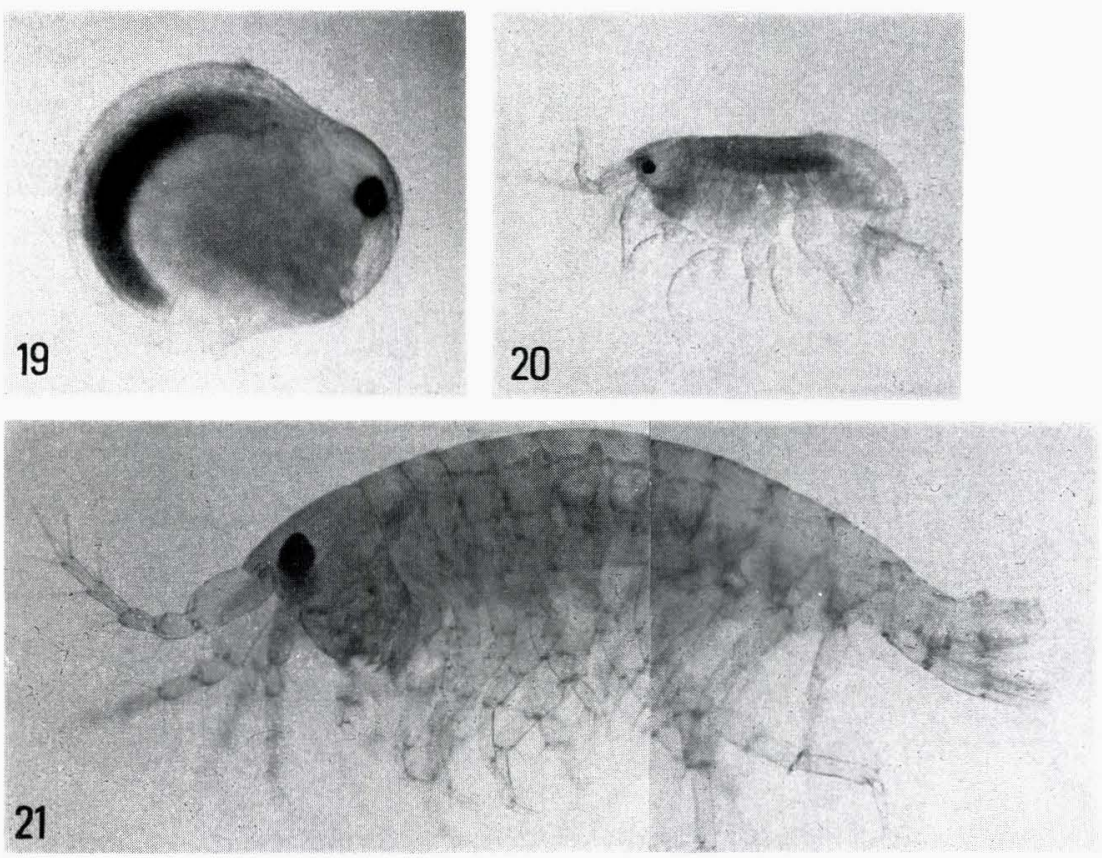

Plate II. Development of Haustorioides japonicus, 13. Dorsal organ forming stage (ventral view). 14. Dorsal organ forming stage (dorsal view). 15. Dorsal organ forming stage $525 \times 475 \mu \mathrm{m}$. 16. Dorsal organ forming stage $550 \times 480 \mu \mathrm{m}$. 17 . Eyes pigment forming stage $600 \times 500 \mu \mathrm{m}$. 18. Eyes pigment forming stage $600 \times$ $500 \mu \mathrm{m}$. 19. Eyes pigment forming stage $650 \times 550 \mu \mathrm{m}$. 20. Hatched juvenile. 21. Juvenile (after $24 \mathrm{hr}$ ) $1.35 \mathrm{~mm}$. 